\title{
Regulating the Sex Trade: A Comparative Study between the Legal Policies Adopted in Selected Countries
}

\author{
JENITA A/P KANAPATHY
}

\begin{abstract}
The term the "oldest profession in the world" often refers to prostitution which had withstood the test of time and thrives in different social orders and societies around the world since antiquity. However, the laws and regulations overseeing this trade will in general vary from nation to nation. In a few nations, the sex trade has been legitimised while in others, it has been criminalised and even decriminalised. Also, there are nations around the world that adopted unregulated policies with respect to the sex trade. This paper distinguishes the kind of legitimate strategies existing around the world in terms of managing the sex trade and analyses the approaches that are adopted by selected nations; which are India, Singapore, Hong Kong and Turkey. Based on the legal framework in the selected countries, the paper recommends conceptual approaches to be undertaken as an alternative to outright criminalisation of the sex trade.
\end{abstract}

Keywords: sex trade, criminalisation; decriminalisation; legalisation; unregulated regime

\section{INTRODUCTION}

The sex trade has distinctive implications to various strata of the public. Each group would view this trade in alignment with their individual economic and cultural belief system. A sex worker may view the sex trade as a livelihood whereas to a religious individual, prostitution is sinful and unacceptable as means of living. To the lawmakers, it requires legitimacy and social acceptance. And, scholars argue it requires examination and data to study on approaches to control, manage or address its issues. To the client of the sex trade, it is simply a business proposition to fulfil his sexual desires. The poor and low middle-income earners will view it as an opportunity to increase income and to enhance a materialistic way of life together with the chance to appreciate the night life of the rich (Shyamala and Siti 1995). The term sex workers and prostitutes would be utilised interchangeably all throughout this paper but carries the same meaning. The term 'sex workers' was introduced by prostitutes themselves to reclassify commercial sex service, with a positive connotation to define it as a form of employment rather than related to any personality characterisation of any class of women whether socially and psychologically (Lynne (1998)). Sex trade alludes to the workers, supervisors, proprietors, advertisers, organizations, clubs and entities associated with both legal and illegal sexual businesses.

\section{COMPETING MODELS RESULTING IN DIFFERENT TYPES OF POLICIES}

Legalising the sex trade is obviously contentious amongst the general population just as in the scholastic field. Three viewpoints in scholastic works see sex trade through profoundly unique models (Ronald 2012). In the opposite ends, we have the empowerment and oppression models and the polymorphous model as a "middle way".

The empowerment model supports the notion that prostitution qualifies as legitimate employment and thus empowers sex workers (Halcyon 2015). This model views sex work as a form of gainful employment equal to other sort of vocations. Empowering scholars contend that issues identified with sex workers are caused by its criminalisation of the sex trade and believe that options in contrast to criminalisation will improve the lives of the sex workers by empowering them with leveraged bargaining position to fight for improved employment conditions instead of docility caused by stigmas attached to the profession.

The oppression model is upheld by a few scholars in opposition to pro-prostitution and it is founded on ultra-feminism. As per this model, socio-economic inequality of the genders is the causal factor that coerced women into sexual servitude to men.

The polymorphous model identifies the pros and cons of the sex trade and takes on a best-fit 
approach. These ideal models are the motivation behind why there are numerous sorts of arrangements managing the regulation of sex trade around the world today.

\section{CRIMINALISATION}

Criminalisation makes the sex trade and related activities offensive with provisions under the various applicable law codes namely using the Criminal Codes or Law to bring it under the purview of the police. Criminalisation tries to decrease or dispense with the sex business and is upheld by the individuals who are against prostitution on good, religious or women's activist grounds (Gangoli, Geetanjali, and Nicole 2006). Countries that have condemned prostitution as criminal can be bifurcated into the prohibitionist approach and the abolitionist approach. Prohibitionist approach takes the view that all types of prostitution are inadmissible and subsequently unlawful. Majority of the states in the US and Middle East adopt this approach.

Conversely, the abolitionist approach, permits the trade of sex, but makes unlawful, all other related activities such as solicitation, profiting from the livelihood of sex workers, establishment of brothels and procurement. This practically criminalises the sex trade as it is impossible to carry out the sex business without getting involved in any of the associated activities as mentioned above (West 2000). The abolitionist approach centres around measures that involves disposing of or diminishing the negative effects of prostitution. This methodology is currently embraced by Malaysia, Britain, and Canada. In countries adopting this approach, perplexity emerges as to its legitimate status because of a tolerant atmosphere practiced towards the sex trade. In such jurisdiction, despite police raids on sex dens and arrests of perpetrators, convictions are seldom executed. This is usual in countries practising this approach.

Sweden was a pioneer in embracing an alternative method called "the Swedish model" in criminalising prostitution by criminalising the purchasers of sex rather than the providers of sex when the Sex Buy Act in 1998 was enacted (Ekberg 2004). This was because Sweden considered prostitution as sexual maltreatment and a demonstration of viciousness against women. Advocates of the Swedish framework believed that by doing this, they can progressively reduce the interest for paid sex and eventually eliminate it.
Rivals of criminalisation contend that criminalisation of the sex trade are looking at the sex trade in a wrong way. They argue that they are fighting sex instead of the crime and does not provide any answer for the issues that sex trade is rooted in (Ine Vanwesenbeeck 2017). An ethnographic research carried out on hostess bar workers in China and women engaged in street-based sex work in the United States and Canada shows that criminalisation results in negative consequences for sex workers' health, safety, and human rights (Susan Dewey, Tiantian Zheng and Treena Orchard 2016). The study evidenced that criminalisation hurts sex workers by potentially confining their work to conceivably hazardous areas, erosion of trust with authorities, further constraining their capacities to discover legitimate work and accommodation and curbing the right of sex workers to establish collective right based associations. The study additionally shows that criminalised sex workers report increased police provocation, seizure of condoms, and confrontational relationship between police and sex workers which gives others the upper-hand to abuse the sex worker without repercussion.

\section{DECRIMINALISATION}

In decriminalisation, all laws against prostitution or any provisions that condemns prostitution are eliminated (Elaine 2007). In decriminalisation, the knowledge of the procurement processes of sexual services are essential. Basically, sex services can be obtained in two noteworthy ways, which are either voluntary and or coerced. The latter should remain a criminal offense if prostitution is decriminalised or even sanctioned especially child prostitution which must not be condoned at any cost. The key distinction between legalisation and decriminalisation is that with the latter, there are no laws to oversee, control and regulate the business. Basically, in decriminalising prostitution, since there are no laws to make prostitution a criminal offense then it is lawful with the exception that it does not violate some other prevailing laws of the state.

Any laws regulating the sex trade is applied equally, just like any other vocation. Therefore, prostitution is perceived as a real business and administered under ordinary occupation and health regulation and is liable to standard local government administrative laws and regulations. Those engaged with prostitution have 
indistinguishable rights and obligations from other works including an obligation to pay all government-imposed taxes. It is appropriate to take note of that decriminalisation and legalisation are different. The fundamental goal of legalisation is to protect social order whereas decriminalisation, specifically targets protection of fundamental rights of sex workers to work with favourable and just employment conditions.

Advocates of decriminalisation contend that the adverse effects in maintaining the position of prostitution as illicit work over-rides its benefits, and as such, ought to be considered as lawful conduct between consenting adults (Jordon 2005). They additionally contend that penalising the sex worker alone and not the customer who is commonly male, reeks of double-standards and inequality. They likewise point to potential infringement of common freedoms that state-directed sanctioning may include, through controls, for example, enlistment and obligatory health checks (Jordon 2005, Mossman 2007). In decriminalisation, there is normally a shift in power from the state and customers to sex workers themselves. Decriminalisation avoids a two-tier operation system of legal and illegal, whereby the latter will work underground. This would remove social exclusions and may subject the sex worker to exploitation and make it more arduous to move out of the sex trade.

At present, NSW Australia and New Zealand have embraced a legal system founded on decriminalisation. In New Zealand, decriminalisation has been the official arrangement since 2003 by the enactment of the Prostitution Change Act. Pursuant to this, a survey was conducted on 772 sex workers using the health services in New Zealand with 58 sex workers subjected to in-depth interview (Abel 2014). The survey outcome demonstrated that after decriminalisation, most sex laborers get regular medical health check-ups. Although decriminalisation does not cause a non-zero level of trafficking, criminalisation does not necessarily eradicate it either. (Samuel, Petra 2015)

\section{LEGALISATION}

When prostitution is legalised, it is lawful as long as it complies to certain state-determined regulation. The basic objective in legalising prostitution is to maintain social order whilst ensuring rights of the sex workers are protected. A few jurisdictions are inclined toward legalisation as a method for mitigating negative components related with prostitution, for example, organised crimes, human trafficking, corruption, prostitution of minors, and to control sexually transmitted diseases (STDs).

Major indicators of a legitimised framework are when there are expressed conditions or constraints imposed by the government. These can be the setting up red light areas, controlling open solicitation in public, registration and licencing of sex workers, obligatory health checks, and periodical inspection of authorised brothels by police, local authorities, or independent specialist boards. Bussinesses or sex workers without the proper authorisation and licenses face criminal punishments. Since legitimisation includes regulation, citizens are more disposed to support these initiatives than decriminalisation.

By and large, nations where sex trade is legalised, human traffic inflows are said to be on the rise (Cho, Axel and Eric 2013). However, the authors admit that more research and data is required to establish a stronger conclusion. This negative result of sanctioned prostitution on a nation's inflows of human trafficking may be believed to support the banning of prostitution (e. g., Outshoorn 2005). Nonetheless, such line of argumentation neglects potential advantages that the legalisation of prostitution may have on those in the sex trade, for example, improved working conditions for sex-workers. Legalisation has been adopted by several nations in Europe such as, the Netherlands, Denmark, Greece, Turkey and by Senegal in Africa, the State of Nevada in the US, and numerous Australian States.

\section{UNREGULATED REGIMES}

Prostitution is completely unregulated in several countries. In these countries, there are no laws either forbidding or permitting prostitution. A survey of 27 nations in Central and Eastern Europe and Central Asia showed that eleven of them did not regulate prostitution. They included mostly Eastern Europe or the former Soviet Union countries (Elaine 2007).

\section{LEGAL FRAMEWORK OF THE SEX TRADE IN INDIA}

Sex trade in India is a USD 8 billion yearly business and $30 \%$ of the sex labourers are children whose 
exploiters gain an astounding USD 2. 2 billion (Dharmendra 2009). The Ministry of Women and Child Development of India revealed that $40 \%$ of an estimated three million sex-workers are children (Goyal and Ramanujam 2014).

The Indian Constitution of 1950, the Indian Penal Code of 1860 and the Immoral Traffic (Prevention) Act of 1956 (PITA) regulate the sex trade in India. Apart from the provisions on equality (Articles 14 and 15 of Part III), the provisions on freedom of association in Article 19(1) and the right to life and personal freedom in Article 21, human trafficking and forced labour are unlawful under Article 26 of the Constitution.

Pursuant to Article 39(e) and (f) of the Indian Constitution 1950, any State policy shall be directed towards ensuring the following;

“.... that the health and strength of workers, men and women and the tender age of children are not abused" and "that the citizens are not forced by economic necessity to enter avocations unsuited to their age or strength" and that "the children are given opportunities and facilities to develop in a healthy manner and in conditions of freedom and dignity" and that the childhood and youth are protected against exploitation and against moral and material abandonment."

Other provisions include, Article 51 that requires the State to always strive to respect international law and treaty obligations. Article 47 of the Constitution also obligates the State to commit itself to "raise the levels of standard of living" and under Article 51(e) promotes the protection of women by obligating the "... renunciation of practices by citizens that are derogatory to the dignity of women".

The main statute related to sex work in India is under the purview of the Immoral Trafficking Prevention Act, 1956 (PITA). PITA imposes punitive measures against pimping, brothel keeping, persons living on earnings of prostitutes and other third-party actions related to the unlawful enrichment from prostitution (Manoj, Sharayu 2008). In fact, Section 3 stipulates inter-alia that “.... any person(s) allowing the use of any premises to be used as a brothel. . ." are liable to be imprisoned.

However, in a few cases, such as Gaurav Jain vs Union of India \& Ors, Ratnamala \& Anor. $v$ Respondent (1962) and Bai Shanta $v$ State of Gujarat, it was noted that the intention of PITA was not to criminalise prostitution but instead aimed at preventing or eradicating the human trafficking related to the commercialisation of the sex trade.

Amendments to PITA were tabled via the Immoral Traffic Prevention Amendment Bill in 2006. The aim of this Bill was to prevent exploitation and trafficking related to the sex trade (Apte, Shankar and Shari, 2008). Hence, prostitution was re-defined as "sexual exploitation or abuse of persons for commercial purposes and a "brothel" as any house or place which is used for purposes of sexual exploitation for the gain of another person or for the mutual gain of two or more prostitutes". The Bill seeks to omit provisions that provide for prosecution against solicitation of clients by individual sex worker.

Though the Bill does not prosecute sex workers if they profit personally from prostitution, it does, however, contain provisions to define the legality of prostitution by placing precedent conditions such as restriction on places where solicitation can be done. Whilst technically prostitution is not criminalised, the conditions are so stringent that it would be onerous to operate any sex trade under such conditions. The Bill had come under criticism as some contended that this may drive the sex trade underground and would defeat the purpose of its amendments which was to provide legal channels of support for victims of human trafficking. The bill also does not provide clarity with respect to the status of sex work as a legal means of living and as such, drew flak from both proponents and opponents of legalisation of prostitution in India. Till to-date, the bill has not been enacted since its proposal in 2006.

Another case involving a Non-Governmental Organisation, Bachpan Bachao Andolan, who filed a Public Interest Litigation (PIL) that brought about the establishment of a panel to investigate their complaint pertaining to large-scale child trafficking. Panel members, Honourable Justices Dalveer Bhandari and A K Patnaik asked the Solicitor General that since curbing prostitution seems to be impossible then it should resort to legalising the sex trade.

In 2009, another interesting case law would be a PIL brought by the Naz Foundation India Trust that petitioned with regards to the application of Section 377 of the Indian Penal Code as discriminatory again homosexuality. The Delhi High Court decided that the provision was unconstitutional, but the Supreme Court overturned this judgement in 2013 citing that legislating or revoking any law is under the jurisdiction of the Parliament and no judicial intervention was needed. The said Court, however, advised Parliament to debate on this matter. Subsequently, in the case of Navtej Singh Johar v Union of India (2018), the Supreme Court reversed the earlier precedence in 
the Naz Foundation case and declared some parts of Section 377 as unconstitutional; effectively decriminalising sexual relationship between consenting adults including homosexuals.

This landmark case caused many to argue that if homosexual relationships can be decriminalised then prostitution should also be accorded the same treatment as long as it is consensual, private and does not involve minors. In recent times, there is an increasing positive push to legalise the prostitution in India to end abuse and trafficking of women and children as well as to reduce the spread of AIDS. However, any measures pushing for such law reforms in India would be painstakingly slow and consume huge amount of resources, given its size in terms of geography, impoverished rural and urban middle-class population and values that are deeply rooted in religion and traditions.

\section{LEGAL FRAMEWORK OF THE SEX TRADE IN SINGAPORE}

Singapore approaches the sex trade from a unique angle whereby there is a difference between the law and its enforcement. Provisions governing the sex trade are stipulated in the Women's Charter (Chapter 353). Sections 146 and 148 of the charter states that activities like pimping, soliciting in public, establishment of brothels, abuse and exploitation of sex workers are unlawful. Every sex worker in the designated red-light areas (DRAs) are registered and accorded a yellow card (Tan and Alisa 2014). Since February 2008, the government enacted amendments to the Penal Code that criminalising prostitution involving a minor under the age of 18 which is punishable by up to seven years in jail (Section 376B). Pursuant to the amendments, there were several convictions, even in a certain case that involved an ex-school principal who was imprisoned for having sex with an under-aged prostitute.

The Women's Charter criminalises prostitution in Section 140, which relates to offences against women that include to sell or to let hire, procure, threat or intimidate, bring or harbour and detain any women against her will regardless if the offence was committed inside or outside of Singapore. The following Section 141 deals with trafficking of women and girls and Section 142 prohibits importation of women or girls under a false pretence.

Under the said Charter, the Director of Social Services is empowered to remove any woman or girls to a safe place or place her under a care of a fit individual until a completion of an enquiry.

Nonetheless, under informal arrangements, brothels can operate in designated red-light areas (DRAs) in Singapore such as Geylang, Keong Saik Street, Flanders Square and Desker Road (Joel 1996). The police branch in-charge of this is the Criminal Investigation Department (CID) ( $\mathrm{Ng}$ 2011). In Singapore, the brothel proprietors are to ensure that sex workers are not under the age of 18 , not abused and have the 'yellow card' as proof that they are free of sexually transmitted diseases (STD).

New prostitutes must be interviewed by the CID to verify that they are working on their own volition and must submit themselves for regular medical check-up. They must surrender their yellow cards and stop working as sex workers if they are tested positive for any sexually transmitted infections (Mee-Lian, Roy, Hiok, Eunice, Lionel, Jeffrey, Joanne and David 2012). If the brothel proprietors conform to the controls laid by the police, they have a chance to work in a well-paying business without any harassment from the police. On top of that, they would be able to complain about any maltreatment, abuses and exploitation to the CID without fear. Upon receipt of any complaint, the CID initiates investigation and would ensure that brother owners keep to their contractual obligation with the sex workers and vice-versa. However, this points to the fact that the existing written laws are unable to deal with the realities on the ground and resorts to informal arrangement which are unlawful, even though, they seem mutually beneficial to all parties involved.

\section{LEGAL FRAMEWORK OF THE SEX TRADE IN HONG KONG}

The current laws in Hong Kong does not criminalise prostitution. Prostitution falls under the purview of Chapter 200 of the Crime Ordinance. Under Part XII - Section 117 of the said Ordinance, prostitute is interpreted as to mean both male or female. The same section also espouses "the One- Women brothel" concept practiced in Hong Kong where in Clause 3(a), the law prohibits any establishment to be used for purposes of prostitution by more than two prostitutes. Though Section 3(b) prohibits the whole and purposeful usage of any place for prostitution, sex trade in Hong Kong generally comprises of women conducting the sex trade in small one-room apartments. Thus, generally termed 
as the "One- girl in one apartment" model. Just like India, Hong Kong also outlaws pimping under Section 137 with imprisonment whereas Section 139 criminalises the establishment of brothels. Despite this, the sex trade in Hong Kong usually involve street-prostitution or entertainment outlets such as massage centres, night clubs and bars. This model of "One- girl in one apartment" seems to be a better arrangement than most other countries including the Singapore model as this averts any intervention of agents or pimps.

\section{LEGAL FRAMEWORK OF THE SEX TRADE IN TURKEY}

The sex trade in Turkey follows the Singapore model but unlike Singapore, prostitution there is legal and regulated. The sex trade is governed by regulatory regimes that controls brothels and sexual practices. As Singapore, Turkey also implements mandatory registration and licensing of sex workers as well as mandatory health screening (Emine and Kyle 2013). Pimping is against the law as per Article 227 (2) of the Turkish Penal Code (Law No. 5237).

Brothels known as "Genelevs" are allowed in Turkey but need to be licenced and screened for sexually transmitted diseases under prevailing health laws. This health screening also applies to the sex workers who are required to be over the age of 18 and single. No married women are allowed to be prostitutes. The verification of compliance to these requirements are carried out by the police.

Registered sex workers in the genelevs are assured protection from police harassment and maltreatment by customers. However, their freedom of movement is curtailed depending on the level of enforcement by the police which may vary from place to place within Turkey. Sex workers are forbidden from working out of genelevs and are required to register any change of genelevs or place of residences with the police. But, in places such as Istanbul, they are accorded the freedom to live outside genelevs or accompany customers to hotels. Sex workers are given special ID cards until they cease working in the sex sector. After which, they are required to surrender their special IDs that is replaced with an ordinary ID card. Even though, they are subject to strict scrutiny and restriction, many women opt to be sex workers due to the lucrative income the sex trade promises. This is fast becoming a difficult and diminishing sector of industry as new recruits to the sex trade are not being registered, growing pressures from pro-religious groups and exploitation from brothel owners who take 40-50 per cent of their income, forcing sex workers to operate illegally.

The way the sex trade operates in Turkey makes it difficult for sex workers to earn a living independently and must subject themselves to the mercy of genelevs unlike the Hong Kong model. Also, though at the face of it, the Turkey model seems to be the same as the Singapore model but in terms of enforcement, the Turkey seems to be lacking in comparison to Singapore and many sex workers in Turkey fall prey to mistreatment by genelevs owners.

\section{CONCLUSION}

Comparative analysis of various policies helps in examining the advantages and shortcomings of different models and to identify the best practices in regulating the sex trade. Legislators may embrace benchmarks of best practices to come up with a legal framework which incorporate visibility, eligibility, health and safety and rights of the sex workers.

Visibility is about keeping the sex trade tactfully far from the public eye or to set up designated red-light areas (DRAs) like Singapore. Turkey has likewise embraced this methodology whereby genelevs are precluded from being noticeable from the main streets, entertainment spots, places of assembling, educational, religious institutions or public authorities. Street prostitutions are also prohibited in Turkey. Eligibility is about implementing administrative regulation in the sex trade to qualify sex workers with respect to a minimum age with the intent of disallowing minors from taking part in the sex trade as child prostitution is criminalised. This methodology has been embraced both by Singapore and Turkey.

Health and safety are another important aspect when regulating the sex sector. The CID in Singapore is given the responsibility to monitor the brothel owners to ensure that the prostitutes are free from sexually transmitted diseases, not below the age of 18 , and are not exploited whereas in Turkey, women who choose to register as prostitutes and work in the genelevs need to undergo regular health check-ups and are assured protection from police intervention and abuse by clients. 
The rights of the sex workers must be taken into consideration when legalizing the sex trade as well. The Hong Kong model allows empowerment to sex workers to work independently and in Turkey sex workers are given the freedom to leave the trade on her own accord.

In countries where prostitution had been criminalized, sex trade continues to thrive. Prostitution will continue to exist, whether legal or not. Hence, rather than taking the drastic approach of Decriminalizing or Criminalizing the sex industry, legislators could look at regulating the sex trade to minimize the harms it causes as well as empowering the sex workers.

\section{REFERENCES}

Abel, Gillian. 2014. Sex workers' utilisation of health services in a decriminalised environment, The New Zealand Medical Journal (Online) 127, no. 1390.

Bai Shanta vs State of Gujarat AIR 1967 Gujarat 211.

Bindman, J. , \& Doezema, J. 1997. Redefining Prostitution as Sex Work on the International Agenda.

Chapman-Schmidt, Ben. 2015: Sex in the shadow of the law: Regulating sex work and human trafficking in Singapore. Asian Journal of Comparative Law 10 (1): 1-21.

Chapter 200 Crime Ordinance

Chatur, D. 2009 Legalization of Prostitution in India. King \& Partridge 60(15): 1-8.

Cho, Seo-Young, Dreher, A. and Neumayer, E. 2013. Does legalized prostitution increase human trafficking? World Development 41: 67-82.

Constitution of India 1950

Dewey, S., Tiantian Zheng, and Orchard, T. 2015. Sex Workers and Criminalization in North America and China: Ethical and Legal Issues in Exclusionary Regimes. Springer.

Ekberg, G. 2004. The Swedish law that prohibits the purchase of sexual services: Best practices for prevention of prostitution and trafficking in human beings Violence against women 10 , (10): 1187-1218.

Evered, E. Ö., and Evered, K. T. 2013. 'Protecting the national body': regulating the practice and the place of prostitution in early republican Turkey. Gender, Place \& Culture 20 (7): 839-857.

Francis, H. 2015. Educating Students About the Social Constructs of Sex Work: Integrating a Course Focused on Prostitution into the Social Work Curriculum.

Friedman, R. I. 1996 India's shame. Nation 262(14): 11-20.

Goyal, Y. and Ramanujam, P. 2014. Ill-conceived laws and exploitative state: Toward decriminalizing prostitution in India. Akron L. Rev. 47: 1071.

Gangoli, G. \& Westmarland, N. 2006. International Approaches to Prostitution: Law and Policy in Europe and Asia. London: The Policy Press.

Gaurav Jain vs Union of India and others AIR 1997 SC 3021.

Gay sex decriminalized in India. 2009. BBC News, July 2, 2009, http: //news. bbc. co. uk/2/hi/south_asia/ 8129 836. stm

Hsien, Ng Hui. 2011. Moral Order Underground : An Ethnography of the Geylang Sex Trade. PhD diss.

Immoral Trafficking Prevention Act, 1956

Indian Penal Code 1860
In Re: Ratnamala and Another vs Respondent AIR 1962 Madras 31

Joel, Wong Yang. 1996. Brothels, Pimps and Prostitutes: The Administration of Criminal Justice vis-a-vis Prostitution. Sing. L. Rev. 17: 154

Jordan, J. 2005. The Sex Industry in New Zealand: A Literature Review. Wellington: Ministry of Justice.

Thottam, J. 2009. India's historic ruling on gay rights, TIME, July 2. http: //content. time. com/time/ world/article/0, 8599, 1908406, 00. html

Lee, Samuel, and Petra Persson. 2015. Human trafficking and regulating prostitution. p. 12-08.

Lim, Gerrie. 2004. Invisible Trade. Monsoon Books.

Lynne, Jacqueline Anne Mary. 1998. Street Prostitution as Sexual Exploitation in First Nations Women's Lives. “ $\mathrm{PhD}$ diss. , University of British Columbia.

Manoj Mitta, 2009 "If gay sex is legal, why not prostitution?" The Times of India, July 11. https: //timesofin dia. indiatimes. com/india/If-gay-sex-is-legal-why-not-prostitution/article show/4764785. cms

Mgbako, Chi, and Laura A. Smith. 2009. Sex work and human rights in Africa. Fordham Int'l LJ 33: 1178.

Mossman, Elaine. 2007. International approaches to decriminalising or legalising prostitution. New Zealand: Ministry of Justice.

Nagaraj, Shyamala, and Siti Rohani Yahya. 1995 The sex sector: An unenumerated economy. Penerbit Universiti Pertanian Malaysia.

Ong, Jin Hui. 1993. Singapore. In Prostitution: An International Handbook on Trends, Problems, and Policies, edited by Nanette J. Davis, 243-72. Westport, CT: Greenwood Press.

Outshoorn, Joyce. 2005. The political debates on prostitution and trafficking of women. "Social Politics: International Studies in Gender, State and Society" 12 (1): 141-155.

Özaşç1lar, Mine, and Neylan Ziyalar. 2015 "Framing Prostitution in Turkey: News Media Coverage of Prostitution." International Journal of Criminal Justice Sciences 10 (2).

P. N. Swamy, Labour Liberation front, Mahaboobnagar v Station House Officer. Hyderabad 1998 (1) ALD 755.

Sahni, Rohini, V. Kalyan Shankar, and Hemant Apte, 2008. eds. Prostitution and Beyond: An Analysis of Sex Workers in India. SAGE Publications India.

Sahyog Mahila Mandal vs State of Gujarat [2004] 2 GLR 1764.

Shi Bin, Tan, \& Alisha Gill. 2013, Containing Commercial Sex to Designated Red Light Areas: An idea past its prime? Singapore: Lee Kuan Yew School of Public Policy.

Tan, Shin Binn, and Alisa Gill. 2014. Containing Commercial Sex to Designated Red Light Areas: An Idea Past its Prime.

Turkish Penal Code (Law No. 5237)

United States Department of State, "2008 Human Rights Report: China (includes Tibet, Hong Kong, and Macau)", Bureau of Democracy, Human Rights, and Labor, 2008 Country Reports on Human Rights Practices, 25 February 2009

Vanwesenbeeck, Ine. 2017. Sex work criminalization is barking up the wrong tree. "Archives of sexual behavior" 46 (6): 1631-1640.

Wad, Manoj, and Sharayu Jadhav. 2008. The legal framework of prostitution in India. Prostitution and beyond: An analysis of sex work in India, p. 207-217.

Weitzer, Ronald. 2012. Legalizing prostitution: From illicit vice to lawful business. NYU Press.

West, Jackie. 2000. Prostitution: Collectives and the politics of regulation. Gender, Work \& Organization 7 (2): 106-118.

Women's Chapter (Chapter 353) 
Wong, Mee-Lian, Roy Chan, Hiok Hee Tan, Eunice Yong, Lionel Lee, Jeffrey Cutter, Joanne Tay, and David Koh. 2012. Sex work and risky sexual behaviors among foreign entertainment workers in urban Singapore: findings from Mystery Client Survey. Journal of Urban Health 89 (6): 1031-1044
Jenita A/P Kanapathy

Taylor's Law School

Faculty of Business \& Law

Taylor's University

Subang Jaya. Selangor

Email: jenita.kanapathy@taylors.edu.my 